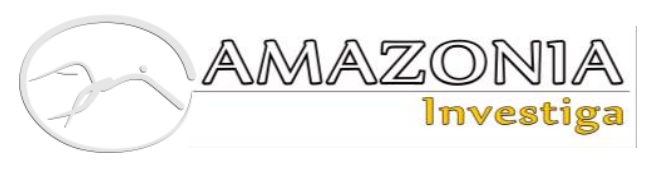

DOI: https://doi.org/10.34069/AI/2021.44.08.11

How to Cite:

Lin, Y., Karabulatova, I.S., Shirobokov, A.N., Bakhus, A.O., \& Lobanova, E.N. (2021). Cognitive distortions in the reflection of civic identity in China: on the material of Russian-language media of East and Western. Amazonia Investiga, 10(44), 115-125. https://doi.org/10.34069/AI/2021.44.08.11

\title{
Cognitive distortions in the reflection of civic identity in China: on the material of Russian-language media of East and Western
}

\section{Когнитивные искажения в отражении гражданской идентичности в Китае: на материале русскоязычных СМИ Востока и Запада}

Received: May 12, 2021

Abstract

This article is devoted to the analysis of cognitive distortion in the mass media as a method of forming a civic identity. Due to the increasing influence of mass media and information technologies, the growth of information impact, the problem of the formation of civil identity is becoming more and more significant, and the mass media is a tool for the formation of civil identity. The authors consider the method of cognitive distortion in the mass media as a method of forming a civic identity in modern media. Culture in the Russian and Chinese traditions reveals both universals and peculiarities. The authors analyze how the attitude to civil identity is transmitted in Russian and Chinese media discourses, which allows us to understand the difference in background knowledge and identify cognitive distortions in translation. The authors see differences in the ethnopedagogic strategies of the state that ensure a positive attitude to civic identity in the Chinese
Accepted: July 21, 2021

Written by:

Yuan Lin ${ }^{45}$

https://orcid.org/0000-0001-5685-2278

Irina S. Karabulatova ${ }^{46}$

https://orcid.org/0000-0002-4228-3235

Alexander N. Shirobokov ${ }^{47}$

https://orcid.org/0000-0001-6946-5912

Aleksei O. Bakhus ${ }^{48}$

https://orcid.org/0000-0001-9738-4896

Elena N. Lobanova ${ }^{49}$

https://orcid.org/0000-0003-4663-815X

\begin{abstract}
Аннотация
Данная статья посвящена анализу когнитивных искажений в средствах массовой информации как метода формирования гражданской идентичности. В связи с возрастающим влиянием средств массовой информации и информационных технологий, ростом информационного воздействия проблема формирования гражданской идентичности становится все более значимой, а средства массовой информации являются инструментом формирования гражданской идентичности. Авторы рассматривают метод когнитивных искажений в средствах массовой информации как метод формирования гражданской идентичности в современных СМИ. Культура в русской и китайской традициях раскрывает как универсалии, так и особенности. Авторы анализируют, как передается отношение к гражданской идентичности в дискурсах российских и китайских СМИ, что позволяет
\end{abstract}

\footnotetext{
${ }^{45} \mathrm{PhD}$ Student of the Department of Foreign Languages, Faculty of Philology, RUDN (Moscow, Russia- Changchun, China)

46 Doctor of Philology, Professor, Research Professor of the Department of Foreign Languages, Faculty of Philology, RUDN (Moscow, Russia)

${ }^{47}$ Candidate of Philological Sciences, Associate Professor, Head of the Department of Modern technologies of mass media and communication of the Faculty of Philology of the RUDN (Moscow)

${ }^{48}$ Senior Lecturer of the Department of Modern technologies of mass media and communication, Faculty of Philology, RUDN (Moscow, Russia)

49 Candidate of Philological Sciences, Associate Professor of the Department of Modern technologies of mass media and communication of the Faculty of Philology of the RUDN (Moscow)
} 
digital space, which has parallels with the Soviet discourse. At the same time, the authors believe that the assimilation of Western models of admiration for their values has a negative impact on the formation of generational continuity and ethno-socio-cultural experience in the traditions of countries.

Keywords: cognitive distortion, mass media, manipulation techniques, pedagogical practices, social and project activities, civic identity, psycholinguistics. понять разницу в фоновых знаниях и выявить когнитивные искажения при переводе. Авторы видят различия в этнопедагогических стратегиях государства, обеспечивающих позитивное отношение к гражданской идентичности в китайском цифровом пространстве, которое имеет параллели с советским дискурсом. В то же время авторы считают, что усвоение западных моделей преклонения перед их ценностями оказывает негативное влияние на формирование преемственности поколений и этносоциокультурного опыта в традициях стран.

Ключевые слова: когнитивные искажения, средства массовой информации, методы манипуляции, педагогические практики, социальная и проектная деятельность, гражданская идентичность, психолингвистика.

the intergenerational dialogue; 3) when using socially oriented activities in team forms, etc.

We consider primarily on the problem of coverage of the topic of China in the media discourse. At the same time, we will use both the data of the Chinese media and the data of the Russian media, which makes it clear how the image of the neighboring country is transformed and deciphered by the bearer of the ordinary Russian linguistic consciousness. The very problem of cognitive distortion can be considered on a separate material of Russian reality. However, we prioritize the analysis of cognitive distortions in portraying the problems of Chinese civic identity through the PRC media and through the Russian media in different languages, respectively.

In modern times, from the point of view of the Chinese worldview, the mass media have a new definition and influence on people of any age. On the one hand, the Chinese media relate to state regulation. On the other hand, the media must earn money from advertising themselves, so the media discourse, the discourse of social media uses new images to attract the attention of a potential audience of recipients.

The Chinese media discourse approaches the problem of civil identity in the same paradigm as the change of the seasons, not only in nature, but also in the person himself, who is completely at the mercy of time. The state is the same living 


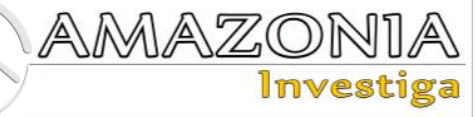

organism as a person, so it is characterized by a time of growth, maturation, and decline. This process is thought to be natural, so any Chinese person treats this fact philosophically, because this is how the world works. The bitterness of withering, like one's own old age, gave birth to sadness, but never to tragedy. Many poetic lines are marked with sadness, since the life span of any organism is relatively modest (Chinese folk wisdom says: "The human age, there are not even hundreds of years in it"), and nature always reminds human society about this. Human life is fragile - it is "not made of metal and stone", it is fleeting, like a flash of lightning.

In this regard, Chinese culture sees an important element of familiarization with a more significant organism - its people, its country. This is how civil identity arises.

Civil identity is an individual sense of belonging to the community of citizens of a particular state, which allows the civil community to act as a collective subject.

Civil identity implies state-civil identity, national-civil identity.

The concept of civil identity itself is implemented in such terms as civil patriotism, state patriotism, patriotic identity, socio-political patriotism, citizenship.

Today, the Chinese media operate at the expense of the state, so they clearly comply with all directives and instructions. At the same time, the number of various media and mass media has increased so much that their content at the expense of the state becomes an impossible task (Stavrov, 2017). In addition, Chinese media have begun to rely on their own income received from the advertising business (Ariely, 2008; Areeva, 2016), and therefore they are forced to adhere to the current trends of society.

We believe that these terms are not clearly attributed enough, making confusion in the terminology apparatus.

The concept of "civil identity", according to several researchers, includes three main elements: cognitive-knowledge of belonging to a given social community, value - the presence of a positive or negative attitude to the fact of belonging, and emotional - acceptance or rejection of the civil community as a membership group, because of the first two actions (Vodolazhskaya, 2010).
The cognitive component forms knowledge about who a citizen is, about the civic community, about state symbols, about the history of the Fatherland and its cultural traditions, about political events taking place in the state, about parties and social movements in the country, about laws, and more (Kostenko, 2012).

We think that it is the cognitive component that is the basis for the development of motives for actions and actions, the content of which is relations that are adequate to the phenomenon of civil identity.

\section{Materials and methods}

The material for the study is the texts of articles about civil identity in Russia and China in modern mass media based on different structural languages. These materials are collected based on a solid sample from print media, social media, and online publications. The limitation of the research material is due to the need to unify the analyzed data, which allows us to fully analyze the variety of reality situations represented in the media discourse. The total volume of the analyzed material is more than 3000 texts.

Various collections of cognitive distortions are widely represented on the Internet (Baer, \& Lubin, 2014; Wikipedia, 2021; Ritholtz, 2012). We analyzed these collections and compiled a list of cognitive distortions from these collections that affect the formation and transformation of civic identity among young people. Next, we have selected those distortions that, firstly, are confirmed and generally recognized, and secondly, affect decision-making in the civil sphere in the field of regulating the choice of strategies for the formation of civil identity among the younger generation. Then we grouped the cognitive distortions into socio-economic categories. This made it possible to illustrate the course of limitations of human social behavior.

The reliability of the obtained research results is ensured by a representative selection of the considered language material, as well as an integrated approach to its analysis, combining the cognitive, critical, and non-rhetorical aspects (Vorozhbitova et al., 2019; Kataev, 2020; Polyakova et al., 2020) of the study of media discourse.

Theoretical research methods: methods of system analysis, synthesis, factor analysis, model approach, methods of generalization and comparison, analysis of statistical and 
sociolinguistic data, correlation analysis, secondary analysis of the results of cognitivepragmatic research.

Empirical research methods: questionnaires, interviews, non-included observation, in-depth interviews.

\section{Results}

We classified the most frequent cognitive distortions found in the Russian-language media in different countries, which made it possible to identify some general patterns in the participation of the manipulume "cognitive distortions" in the transformation of the perception of civic identity both in China itself and beyond.

The press moves away from the coordination of various interests when it simplifies life conflicts, idealizes, or demonizes political figures of the past or present, reveals some circumstances and ignores others, as well as various points of view (Polyakova et al., 2020). The mass media focus on the differences that exist between social groups, political and economic actors, and not on the search for compromises, agreement. The simplification and stereotyping of information policy leads to the fact that the press mainly reflects the manifestations of a formalized identity, the participation of people in public actions on the initiative of political or economic subjects, focuses attention on scandalous circumstances associated with the lives of famous people. Less often, the press tries to comprehend the motives of an individual participating in public activities, to identify which interests attract him-social, political, or personal, to reveal the meaning of diverse civil initiatives, horizontal communication links.

The term "manipuleme" was introduced by I. S. Karabulatova in the definition of a manipulative technique used to change the attitude towards something or someone (2020a). Later, this term was considered in detail by I. P. Savchuk in the system of manipulative media discourse (2021). At the same time, Yongchen Ruan and I. S. Karabulatova (2021) made significant clarifications in the definition of manipuleme, based on the analysis of fiction and documentary film discourse of China and Russian Empire.

Nevertheless, the press can participate in the formation of an individual's active position, to serve as an institution for coordinating social, political, and personal interests.

First, the attempts of the mass media to reveal the civil potential of people, to instill in them confidence in their own capabilities, are useful. According to sociologists, a considerable part of the local community, about a fifth of the residents of the municipality are characterized by initiative and responsibility, enthusiasts can become the core of local self-government, involve potentially active people in solving problems.

As a rule, a positive response, a desire to understand one's place in the life of the country, region, and local community is caused by messages about the social creativity of fellow citizens, about their participation in legislative, volunteer, and charitable activities.

Mass media encourage many people to act for the common good, when they spread the ideas of self-regulation and self-organization of society, information about the activities of civil activists who are forced to replace the authorities in solving acute social problems, represent not only different points of view, but also argumentation, systems of views shared by participants in competitive interactions taking place in the socio-political sphere.

Secondly, the mass media would provide a service to society if they identified opportunities for using tools of civil control and examination of socially significant programs and projects, expanding cooperation between authorities and experts in assessing and monitoring the state of institutions, as well as public policy actors. 
Table 1.

Classification of cognitive distortions according to the directions of influence on the civil identity of a person

\begin{tabular}{|c|c|c|c|c|c|c|}
\hline № & Criteria & \multicolumn{5}{|c|}{ Cognitive distortions } \\
\hline 1 & Hazard/ risk & \multirow{2}{*}{$\begin{array}{l}\text { risk aversion } \\
\text { Post-purchase } \\
\text { rationalization }\end{array}$} & \multicolumn{2}{|c|}{ Zero-risk bias } & \multicolumn{2}{|c|}{ Pseudo certainty effect } \\
\hline 2 & rationality & & \multicolumn{2}{|c|}{ Wishful thinking } & \multicolumn{2}{|c|}{ Bandwagon effect } \\
\hline \multirow{2}{*}{3} & \multirow{2}{*}{ information } & Information bias & $\begin{array}{l}\text { Confirmation } \\
\text { bias }\end{array}$ & \multicolumn{2}{|c|}{ Authority bias } & $\begin{array}{l}\text { Availability } \\
\text { heuristic }\end{array}$ \\
\hline & & Framing effect & $\begin{array}{l}\text { Ambiguity } \\
\text { effect }\end{array}$ & \multicolumn{2}{|c|}{ Anchoring } & $\begin{array}{l}\text { Self-fulfilling } \\
\text { prophecy }\end{array}$ \\
\hline 4 & time & \multirow{3}{*}{$\begin{array}{l}\text { Planning fallacy } \\
\text { Moral credential } \\
\text { effect } \\
\text { the effect of } \\
\text { disinformation }\end{array}$} & & \multirow{3}{*}{\multicolumn{2}{|c|}{$\begin{array}{l}\text { Gambler's fallacy } \\
\text { the effect of } \\
\text { authority } \\
\text { false memory }\end{array}$}} & \\
\hline 5 & rules and & & Amplification & & & $\begin{array}{l}\text { The henomenon } \\
\text { of a "just world" }\end{array}$ \\
\hline & regulations & & $\begin{array}{l}\text { processing level } \\
\text { effect }\end{array}$ & & & $\begin{array}{l}\text { imaginary } \\
\text { constancy }\end{array}$ \\
\hline
\end{tabular}

There is no doubt that the comparison of cognitive distortions and socio-pedagogical categories cannot be unambiguous. For example, the effect of mass infatuation can be not only a consequence of violating the requirement for rationality, but also a property of economic an institution that pushes individuals to violate their own interests in such a way that it is necessary to classify these distortions in the form of a graph with edges of different connection strength rather than in the form of a linear comparison, as we did in the table. However, we have made some correspondence in the table with the most strongly related phenomena, which, given the requirement of ceteris paribus, is quite sufficient.

People extract information from the mass media, which creates a natural course of formation of cognitive distortion in civil identity, since recipients unconsciously perceive meanings distorted due to their own background knowledge, which leads away from the goal of the original propaganda discourse. This aspect is especially important in the aspect of adaptation of migrants in the host community (Ebzeeva, Karabulatova, \& Nakisbaev, 2018; Xia, 2008; Niijati et al, 2020), while the "friend-foe" dichotomy is exacerbated (Luchinskaya et al., 2018; Sautieva et al., 2020).

Russian mass-media discourse used to position the geopositioned China itself as a designation of Evil (since the sacred image of the dragon in Chinese culture is perceived as a symbol of devilish forces in Russian culture), now the focus is shifting towards emphasizing common features between Russians and Chinese. In the context of civic identity, this is an emphasis on the community mentality. At the same time, familiarity with Chinese linguistic culture forms respect, and sometimes admiration among
Russian respondents, which is associated with China's success in scientific and technological progress. At first, in the Chinese media discourse, China and Russia are positioned as partners and successors of the great Soviet past, which creates a sense of pride in the common history of the era of socialism in the context of creating a positive civic identity. Actions for the formation of a positive civic identity are events for the dates of the Communist Party of China, for the dates of the Second World War, etc.

An important component is the use of information technologies and means of positive communication on the Internet, without which it is impossible to imagine the life of the younger generation. Technologies of mobile learning, virtual communication, electronic news actualize the need for the younger generation to form competencies for creating and maintaining thematic blogs (for example, an algorithm for meeting and communicating with peers from other countries in social networks, etc.; or creating video content in blogs about the progress and results of implementing their own projects; training in the skills of presentation of work with blogs (about "traces of activity", impressions of communication with foreigners, etc.).

The system of discursive dominants of the mental space of personal effectiveness is formed due to the concretized attitudes of the general selfattitude to success, which stimulates the activitycommunicative needs of the recipient's pragmatist with the transition to the autocommunication mode. However, the very stereotype of the country and civil identity begins to be perceived as integral components of the image of the country with which the recipient identifies himself, therefore, civil identity is formed based on associations, background 
knowledge about the country and ethnic group, and therefore it is always ethno-culturally and ideologically conditioned. This understanding of civic identity gives us the opportunity to go beyond the limits of sociological discourse, turning it into the field of linguistics and pedagogy (Erina et al., 2020).

We must distinguish between "misunderstanding" and "delusion". The socalled misunderstanding refers to a misunderstanding. The implicit precondition is based on the information as a standard. Any understanding that differs from the intention of the author of the propaganda is a misunderstanding. When the recipient receives information, he has a lot of ideas that vary from person to person, so a certain degree of cognitive bias is inevitable.

In this regard, we can divide the producers of mass media discourse that affect the multivariability of cognitive distortions into two types: 1) official media and 2) unofficial media.

Unofficial media are represented by the following subtypes:

1) Personal (author's, private, personal) blog / website / page;

2) Bot blog (a special program for the purpose of identifying and collecting information);

3) An anonymous (ghost) blog / website / page on behalf of a fictional character, with the concealment of real data about the author;

4) Fake blog (on behalf of publicity, etc.);

5) Corporate blog (the page of any department, institution on the Internet);

6) Vlog (video channel on behalf of someone or something;

7) Advertising page (promotion of a person/ group of persons/ enterprise on the Internet);

8) Social page (social interest group).

For example, a group of social blogs written by representatives of various social groups (disabled people, parents, migrants, etc.) is widely represented in the mass media. For example, some migrants themselves write on their pages in the mass media about the problems of forming identity and preserving the ethno-cultural value of the host community. These expats talk about life in the country "from the inside", illustrating the process of adaptation, acculturation in the host community.

Any person makes decisions differently in a situation involving a particular risk. In conditions where there are risks, certain cognitive distortions are reflected, for example, risk aversion, preference for zero risk, the effect of pseudo-confidence. An example of cognitive distortion is the phenomenon of a "just world" and the effect of an identifiable victim when children and adolescents are used in military operations as hostages and/or participants in illegal actions (Bazhanov, 2021; Kozyrev, 2021).

One and the same event - student protests in Hong Kong are presented differently in the state Russian media (Kozyrev, 2021) and in the Russian-language Western media (Bazhanov, 2021). Thus, P. Bazhanov emphasizes that the leading slogan of the protests was "Freedom to Hong Kong. The Revolution of Our Day", indicating that Hong Kong demonstrates a formed regional identity that differs from the civic identity of the rest of mainland China. At the same time, the journalist cites certain historical facts that led to the awareness of the people of Hong Kong of their exclusivity and formed their understanding of democratic freedoms of the Western type as opposed to traditional social behavior in China. In this regard, P. Bazhanov writes: "China endured opposition in Hong Kong for a long time, but now decided to finally tighten the screws. Meduza tells how democracy was born in the city-state - and how it was killed" (Bazhanov, 2021, electronic resource). At the same time, P. Bazhanov uses such a widespread method of cognitive distortion as selective perception, when only those facts are considered that are consistent with expectations.

At the same time, D. Kozyrev (2021) explains why the destruction of human rights organizations is a positive fact for the Chinese society. He notes that most of the youth organizations of the Democratic type in Hong Kong have self-disbanded due to the loss of the need for their existence. So, D. Kozyrev uses methods of devaluation and generalization, pointing out that "demonstrations were organized (...) and turned into something like a carnival for Venice: how could it be without him? in any society" (Kozyrev, 2021, electronic resource).

We believe that a critical approach to materials of this kind allows the recipient of mass media discourse to form his own point of view, which can either coincide with the point of view of a particular media outlet or can help his own idea of a particular situation, fact, event, phenomenon, person. We think that a diverse and sometimes contradictory presentation of the same events contributes to the formation of an 


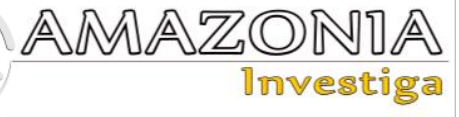

objective view that reflects different points of view.

Nevertheless, it is the media discourse that can form an active life position of an individual, reflecting the activities of social institutions to coordinate social, political, and personal interests.

\section{Discussion}

Modern media discourse, regardless of the language, has a special form of discursive representation of reality, which is designated as mediatization. We understand by mediatization the discursive processing of reality by writers either by the type of "reflection" or by the type of "construction".

N. Luhman, a researcher of media communication, clarifies that any communication acts as a kind of synthesis of three selections consisting of information, communication and understanding (Luhman, 2005: 7). The main function of communication is to unload and expand the cognitive abilities of people (Aipova et al., 2021). A person "can perceive at a distance, and this opportunity, acquired by a person in the course of evolution, cancels the need for him to get all the information himself, because with the help of others, you can get much more information" (Luhmann, 2005: 9). N. Luhmann also puts forward the hypothesis that modern society is a society as a medium (Der Massenmedien), or a system of communications that constitute themselves by distinguishing between the medium and the form. This system "makes it possible for people to communicate selectively with each other while maintaining their independence from each other" (Luhmann, 2005: 11).

It is no secret that news is texts that maximize the main function of mass communication informative. The comment combines the implementation of the message function with the strengthening of the impact component through the expression of opinion and evaluation. Journalistic texts are characterized by a further strengthening of the impact in its artistic and aesthetic version (Dobrosklonskaya, 2010: 30). The difference from the classification of B. A. Zilbert (1986) is the addition of advertising, which combines the influencing function in two forms: as "a function of language realized through linguistic means, and as a function of mass communication realized with the help of special media technologies" (Dobrosklonskaya, 2010: 33).
Researchers note various reasons and sources for the formation of cognitive distortions as a kind of social phenomenon (Karabulatova et al., 2017; Kashapova \& Ryzhkova, 2015). Here, emotional, moral, and ethical reasons, the limited capabilities of the brain for processing information, the specifics of encoding and decoding information, etc. are brought to the fore.

Behavioral models were developed by psychologists to determine the specifics of the conditions for the manifestation of cognitive distortions, considering the causes. Modern researchers (Kryukova et al., 2018) point out that errors in the social behavior of individuals in the conditions of choosing a decision strategy are systemic in nature, and therefore quite measurable. The phenomenon of cognitive distortions itself refers not so much to the requirements regarding oneself or others, as to the secondary emotional coloring of upcoming or current events. This emotivity of the event is due to the previous experience of the individual and his background knowledge. As a rule, most irrational beliefs are directly related to the immediate personal experience of the individual himself, while cognitive distortions have a variety relative to their object.

The issue of the formation of civic identity in the conditions of modern Russia acquires a high degree of relevance in the situation of rejection of official forms of social activity among young people (Gadzhimuradova, 2009; Semenova, 2010). While in China, this issue is aggravated due to the protest behavior of Chinese youth (Dong \& Korzhova, 2017), which is expressed in apathetic passive social behavior, the symbol of which is Lelouch (Lisitsa, 2021). Social nihilism, hedonism, social apathy, and laziness in Chinese youth culture have become a response to the intensive exploitation of motivation factors without considering the work of the psyche, for the functioning of which it is important to change the modes of work and rest. As a result, the mass media present the audience with transformed personal myths and changed legends (Savchuk et al., 2019; Kloet and Fung, 2017), which also contributes to the spread of cognitive distortions in society.

The cognitive component forms knowledge about who a citizen is, about the civic community, about state symbols, about the history of the Fatherland and its cultural traditions, about political events taking place in the state, about parties and social movements in the country, about laws, and more. Researchers 
rightly note that it is the cognitive component that is the basis for the development of motives for actions and actions, the content of which is relationships that are adequate to the phenomenon of civil identity (Efimenko, 2013; Xi \& Xia, 2006).

At the end of the XX century, a fundamentally new environment began to form, where all spheres of life are directly related to the use of information, which categorically changes the living conditions, culture, and behavior stereotypes (Voronina, 2014; Khachmafova et al., 2017; Minhua, 2017; Kyrychenko et al., 2021; Entina et al., 2021). As a result, information becomes one of the most important means of influencing public opinion and public behavior, i.e., a management tool. Modern life is becoming more and more dependent on the quantity and quality of the information provided. Today, information is no longer an insignificant attribute of social development, rather, on the contrary, it is a strategically important resource (Barabash et al., 2019; Golubtsov et al., 2019; Pastukhova, 2018; Polyakova et al., 2020).

Our research is since when making social decisions about one's own identity, an individual is prone to making mistakes under the influence of various psychological factors and socioeconomic conditions.

\section{Conclusion}

Now is the information age, and the role of mass media in public life is becoming more and more noticeable, since they carry potential dangers (Karabulatova, 2020). People's work and life are inseparable from the demand for information. Constantly updated mass media meets the needs of people and becomes an indispensable tool for them to understand external information. Political construction, economic prosperity and cultural integration depend on the help of the mass media.

The technological changes and social impact caused by mass media are enormous. In the information environment created by the mass media, network users suffer most from the impact of information life in the era of new media. With such an impact, network users consciously or unconsciously create certain cognitive distortions, including a cognitive distortion of civil identity.

Cognitive distortions are corrected primarily due to the media discourse and psychological and pedagogical practice, which uses the achievements of cognitive behavioral practice, psychotherapy. In fact, to correct cognitive errors and change irrational beliefs, a high level of selfreflection and critical thinking using introspection is required, since it is necessary to have the ability to catch those thoughts that cause discomfort, inflate negative emotions. Thanks to purposeful work, cognitive distortions can be weakened and leveled.

\section{Bibliographic references}

Aipova, A., Apaeva, A., Temirgalinova, A., Shabambaeva, A., \& Karabulatova, I. (2021). The features of the formation of ethno-value consciousness in the modern Kazakh Pedagogical University. Revista de Tecnología de Información y Comunicación en Educación, 15(2), 229-244, DOI: https://doi.org/10.46502/issn.18567576/2021.15.02.18

Areeva, M. V. (2016). On the question of the legal basis of the information policy of the FRG. Actual problems of modern international relations, $8 . \quad$ URL: https://cyberleninka.ru/article/n/k-voprosuo-pravovoy-osnove-informatsionnoypolitiki-frg (accessed: 28.07.2021).

Ariely, D. (2008). Predictably irrational: The hidden forces that shape our decisions. New York, NY: Harper Collins, 304 p. ISBN 9780-06-135323-9

Baer, D., \& Lubin, G. (2014). Cognitive Biases That Screw Up Everything We Do. Business Insider Inc., 12, $43 . \quad$ URL: http://www.businessinsider.com/cognitivebiases-2014-6?op=1(date of access: 31.05.2021).

Barabash, V.V., Kotelenets, E.A., Karabulatova I.S., Lavrentyeva M.Y., \& Mitina Y.S. (2019). The confrontation between the Eastern and Western worldviews in the conceptual space of the information war against Russia: the genesis and evolution of the terminological apparatus. Amazonia investiga, 8(19), $246 \quad-254$. https://amazoniainvestiga.info/index.php/am azonia/article/view/226

Bazhanov, P. (2021). China endured opposition in Hong Kong for a long time, but now decided to finally tighten the screws "Meduza" tells how democracy was born in the city-state - and how it was killed. "Meduza", [Electronic resource]: https://meduza.io/feature/2021/07/31/kitaydolgo-terpel-oppozitsiyu-v-gonkonge-noteper-reshil-okonchatelno-zakrutit-gayki (date of base 18.08.2021). 


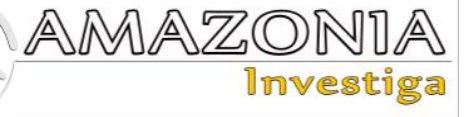

Dobrosklonskaya, T. G. (2010). Questions of studying media texts: the experience of studying the modern English media language. 3rd ed. Moscow: URSS, 286 p.; ISBN 978-5396-00100-8.

Dong, Y., \& Korzhova, E. Yu. (2017) Values of modern Chinese youth. Kazan Bulletin of young Scientists, No. 1 (1). URL: https://cyberleninka.ru/article/n/tsennostisovremennoy-kitayskoy-molodezhi (accessed: 03.08.2021).

Ebzeeva, Y.N., Karabulatova, I.S., \& Nakisbaev, D.A. (2018). The Problems of Transformation of the personal Identity in a modern migrant. Astra Salvensis, 6, 1, 729-738.

Efimenko, V. N. (2013). Structural components and content of the concept of "Civil identity". Theory and practice of social development, 11. URL: https://cyberleninka.ru/article/n/strukturnyekomponenty-i-soderzhatelnoe-napolnenieponyatiya-grazhdanskaya-identichnost (accessed: 03.08.2021).

Entina, T., Karabulatova, I., Kormishova, A., Ekaterinovskaya, M. \& Troyanskaya, M. (2021). Tourism Industry Management in the Global Transformation: Meeting the Needs of Generation Z. Polish Journal of Management Studies, 23(2), 130-148. DOI: 10.17512/pjms.2021.23.2.08

Erina, I. A., Mutaliyeva, A., Mikhalkova, O., \& Brevnova, S. (2020). Psychological Correction of Aggressive Behavior of Older Preschool Children in Fairy-Tale Therapy Discourse. Amazonia Investiga, 9(29), 297-306. https://doi.org/10.34069/AI/2020.29.05.34

Gadzhimuradova, Zh. T. (2009). Features of ethnic and civil identities in the selfconsciousness of the Russian youth of Dagestan. Izvestia of the DSPU. Psychological and pedagogical sciences, 4. URL:

https://cyberleninka.ru/article/n/osobennostietnicheskoy-i-obschegrazhdanskoyidentichnostey-v-samosoznanii-russkoymolodezhi-dagestana (accessed: 03.08.2021).

Golubtsov, S., Zelenskaya, V., Luchinskaya, E., Kanon, I., Karabulatova, I., \& Kalkeeva, K. (2019). Changing the functions of language in the modern linguistic paradigm: Influence of virtual discourse. Amazonia Investiga, 8(22), 665-672. Retrieved from https://amazoniainvestiga.info/index.php/am azonia/article/view/817

Karabulatova, I. (2020). Possibilities of artificial intelligence in assessing the impact of potentially dangerous texts in modern news discourse: problem of statement. International Scientific Forum "Issues of Modern Linguistics and the Study of Foreign Languages in the Era of Artificial Intelligence (dedicated to World Science Day for Peace and Development)" (LLT Forum 2020) Vol 88,

DOI https://doi.org/10.1051/shsconf/2020880100 1

Karabulatova, I. (2020a). The Manipulation of the Public consciousness through Russian Press Coverage of Events around the Paris Peace Conference, 1918-1920. The Paris Peace Conference (1918-1920) and Its Aftermath: Settlements, Problems, Perceptions. Edited by Sorin Arhire and Tudor Roșu. London: Cambridge Scholars Publishing, pp. 209-227. ISBN (10), 1-52754224-6 ISBN (13), 978-1-5275-4224-2 Retrieved from https://cambridgescholars.com/product/9781-5275-4224-2

Karabulatova, I., Vildanov, Kh., Zinchenko, A., Vasilishina, E., \& Vassilenko, A. (2107). Problems of transformation matrices modern multicultural identity of the person in the variability of the discourse of identity Electronic Information Society. Pertanika Journal of Social Science \& Humanities, 25(S). 1-16. Retrieved from: http://www.pertanika.upm.edu.my/Pertanika \%20PAPERS/JSSH\%20Vol.\%2025\%20(S) \%20Jul.\%202017/JSSH(S)-0376-2017.pdf

Kashapova, E. R., \& Ryzhkova, M. V. (2015). Cognitive distortions and their impact on individual behavior. Bulletin of the Tomsk State University. Economy, 2 (30), 15-26, DOI 10.17223/19988648/30/2

Kataev, P. V. (2020). Cognitive distortion as a position of analysis of a journalistic text (based on material of multimedia music reviews). Sign: a problematic field of media education, 4 (38). Retrieved from: URL: https://cyberleninka.ru/article/n/kognitivnoeiskazhenie-kak-pozitsiya-analizazhurnalistskogo-teksta-na-materialemultimediynyh-muzykalnyh-retsenziy (accessed: 28.07.2021).

Khachmafova, Z.R., Karabulatova, I.S., Serebryakova, S.V., Zinkovskaya, A.V., Ermakova, E.N. (2017). The Specifics of an Estimate discourse of gender stereotypes in small forms of Folklore in a Network Discourse of Electronic and Information society at the Beginning of 21ct Century. Pertanika Journal of Social Science \& Humanities, No. 25 (S), p. 137-150. Retrieved from http://www.pertanika.upm.edu.my/resources 
/files/Pertanika\%20PAPERS/JSSH\%20Vol. $\% 2025 \% 20(\mathrm{~S}) \% 20 \mathrm{Jul} . \% 202017 / \mathrm{JSSH}(\mathrm{S})-$ 0385-2017.pdf

Kloet, J. de and Fung, A. (2017). Youth Cultures in China. Cambridge, United Kingdom: Malden, MA, Polity Press, 229 p.

Kostenko, E. V. (2012). Cognitive aspect of the influence of network media on mass consciousness. Bulletin of the National State University, 5-3. URL: https://cyberleninka.ru/article/n/kognitivnyyaspekt-vliyaniya-setevyh-smi-na-massovoesoznanie (accessed: 28.07.2021).

Kozyrev, D. (2021). The city was left without human rights defenders. Why this is good news. RIA-Novosti, [Electronic resource]: https://ria.ru/20210819/gonkong1746260043.html (date of base 19.08.2021)

Kryukova, T. L., Ekimchik, O. A., Khokhlova, Yu. A., \& Kirpichnik, O. V. (2018). The phenomenon of cognitive distortions of subjective evaluations of life phenomena and their measurement (primary adaptation to the Russian language of the cognitive distortion scale - CdS). Bulletin of the Kostroma State University. Series: Educators. Psychologists. Sosiokinetics, 4.4 URL: https://cyberleninka.ru/article/n/fenomenkognitivnyh-iskazheniy-subektivnyhotsenok-zhiznennyh-yavleniy-i-egoizmerenie-pervichnaya-russkoyazychnayaadaptatsiya (data abratsheniya: 03.08.2021).

Kyrychenko, M., Nikitenko, V., Voronkova, V., Harbar, H., \& Fursin, A. A. (2021). The search for new forms of personal expression in the era of postmodernism. Amazonia Investiga, $\quad 10(42), \quad 248-254$. https://doi.org/10.34069/AI/2021.42.06.23

Lisitsa, A. (2021). Lelouch was accused of promoting laziness after the Chinese "Star Factory". Gazeta.ru [Electronic source]: https://www.gazeta.ru/culture/news/2021/05/ $31 / \mathrm{n}$ 16042940.shtml (date of base 05.06.2021).

Luchinskaya, E. N., Karabulatova, I. S., Tkhorik, V. I., Zelenskaya V. V., \& Golubtsov S. (2018). New aspects of intercultural communication discourse modeling in the context of globalization and migration. Opción, No. 85, 789-800, ISSN 10121587/ISSNe: 2477-9385 http://www.produccioncientifica.luz.edu.ve/i ndex.php/opcion/article/view/24034

Luhman, N. (2005). The reality of mass media. M.: Praxis, (JSC Tip. News). 253 p.; ISBN 5-901574-46-X.

Minhua, L. (2017). Jeroen de Kloet and Anthony Fung, Youth Cultures in China. China Perspectives [Online], URL: http://journals.openedition.org/chinaperspect ives/7436; DOI: https://doi.org/10.4000/chinaperspectives.74 36

Niijati, A., Karabulatova, I., Yuan L., and Sautieva, F. (2020). Problems of cognitive distortions in cross-cultural communication when using automatic translation in the Russian Chinese dialogue. International Scientific Forum "Issues of Modern Linguistics and the Study of Foreign Languages in the Era of Artificial Intelligence (dedicated to World Science Day for Peace and Development)" (LLT Forum 2020) Vol 88,

DOI https://doi.org/10.1051/shsconf/2020880300 4

Pastukhova, L. S. (2018). Pedagogical practices of formation of civil identity of youth. Values and meanings, No. 4. URL: https://cyberleninka.ru/article/n/pedagogiche skie-praktiki-formirovaniya-grazhdanskoyidentichnosti-molodezhi (accessed: 03.08.2021).

Polyakova, L., Yuzhakova, Y. V., Zalavina, T., \& Dyorina, N. (2020). Linguistic Manipulation Means in English Political Discourse. Amazonia Investiga, 9(33), 27-36. https://doi.org/10.34069/AI/2020.33.09.3

Ritholtz, B. (2012). Investors' 10 most common mistakes. The Washington Post. URL: http://www.washingtonpost.com/business/in vestors-10-most-common-mistakes/2012/07 /09/g JQAZQh1cW _story.html (date of access: 31.07.2021).

Ruan, Yu., \& Karabulatova, I.S. (2021). The Experience of the Loss of the Motherland by Representatives of Russian Emigration in the Chinese Provinces (1905-1917). Bylye Gody, 16(3), 1501-1510. DOI: 10.13187/bg.2021.3.1501

Sautieva, F.B., Baltabayeva, Z. B., Skorobogatova, A. G., \& Mamatelashvili, O.V. (2020). The impact of success factors on the strategic management in an educational. Amazonia Investiga, 9(29), 336-346. https://amazoniainvestiga.info/index.php/am azonia/article/view/1400

Savchuk, I. P. (2021). Evolution of the mytholinguistic characteristics of the geopolitonym Siberia (based on the material of modern media). (Abstract of the dissertation for the degree of candidate of philological sciences). RUDN, Moscow, 25 p. http://dissovet.rudn.ru/weblocal/prep/rj/dis/download.php?file $=168 f 530$ faed1581ea79340d70daa8e4014772 
Savchuk, I. P., Karabulatova, I. S., Golubtsov, S. A., Zelenskaya, V. V., Akhmetova, B. Z. (2019). Language features of the legend's genre as the basis of storytelling technology in advertising discourse. Amazonia investiga, 8(21), pp.522 - 530. https://amazoniainvestiga.info/index.php/am azonia/article/view/132

Semenova, Yu. A. (2010). Formation of civil identity in the conditions of modern Russian society. Bulletin of ChelSU, 1. URL: https://cyberleninka.ru/article/n/formirovani e-grazhdanskoy-identichnosti-v-usloviyahsovremennogo-rossiyskogo-obschestva (accessed: 03.08.2021).

Stavrov, I. V. (2017). The image of Russia on the pages of the newspaper "Heilongjiang Zhibao". Oikumena. Regional studies, 1 (40). URL: https://cyberleninka.ru/article/n/obrazrossii-na-stranitsah-gazety-heyluntszyanzhibao (accessed: 28.07.2021).

Vodolazhskaya, T. (2010). Identity civil. Educational policy, 5-6. pp. 140-142.

Voronina, D. G. (2014). Mass media as a factor in the formation of Russian identity. Social and humanitarian knowledge, 11. URL: https://cyberleninka.ru/article/n/mass-mediakak-faktor-formirovaniya-rossiyskoyidentichnosti (accessed: 03.08.2021).
Vorozhbitova, A., Karabulatova, I., Bzegezheva, Z., Druzhinina, V., \& Pyankova, T. (2019). A glossy magazine discourse of the early twenty-first century as a tool of globalization: Sochi school of linguistics and rhetoric. Amazonia Investiga, 8(24), 170-180. Retrieved from https://amazoniainvestiga.info/index.php/am azonia/article/view/969

Wikipedia. (2021). List of Cognitive Biases. The Free Encyclopedia. URL: http://en.wikipedia.org/wiki/List_of_cogniti ve_biases (date of access: 01.08.2021).

Xi, J., \& Xia, Y. (2006). Introduction to Chinese Youth (with a Commentary). Faculty Publications from Nebraska Center for Research on Children, Youth, Families, and Schools, 2, 79-105. https://digitalcommons.unl.edu/cyfsfacpub/2

Xia, S. (2008). The concept of CHINA in the Russian everyday language consciousness. (abstract of the dissertation of the Candidate of Philological Sciences) Lomonosov Moscow State University, Moscow, 24 p. https://www.studmed.ru/shi-sya-konceptkitay-v-russkom-obydennom-yazykovomsoznanii_dfb7a0f728c.html

Zilbert, B. A. (1986). Sociopsycholinguistic research of texts of radio, television, newspapers. Saratov: Saratov Publishing House. un-t, 210 p. 